\title{
Preparation of Gentamicin Conjugated Cellulose Nanocrystals and Evaluation of Efficacy on Different Microorganisms
}

\author{
Aydan Gülsu ${ }^{1 *}$, Ecem Yüksektepe ${ }^{2}$ \\ ${ }^{1 *}$ Muğla Sttkı Koçman University, Molecular Biology and Genetics Department, Muğla, Turkey (ORCID: 0000-0001-5026-6868 gaydan@mu.edu.tr \\ ${ }^{2}$ Fenerbahçe University, Pathology Laboratory Techniques Department, İstanbul, Turkey (ORCID: 0000-0002-8041-2915) ecem.yuksektepe@fbu.edu.tr
}

(First received 23 June 2021 and in final form 20 October 2021)

(DOI: 10.31590/ejosat.956593)

ATIF/REFERENCE: Gülsu, A. \& Yüksektepe, E. (2021). Preparation of Gentamicin Conjugated Cellulose Nanocrystals and Evaluation of Efficacy on Different Microorganisms. European Journal of Science and Technology, (27), 1105-1112.

\begin{abstract}
Large amounts of waste cotton material generated in textile production cause environmental problems and resource depletion. The production of nanocrystalline cellulose is one of the effective way to the recycling of waste cotton. Cellulose nanoparticles are of great interest in biomedical applications due to their various properties. In this study cellulose nanocrystals were produced from waste cotton through acid hydrolysis in a single step. The extraction of cellulose from waste cotton was carried out by alkaline treatment, afterthat the cellulose nanocrystals were isolated by the nitric acid $(68 \% \mathrm{w} / \mathrm{w})$ and hydrochloride acid $(37 \% \mathrm{w} / \mathrm{w})$ mixture acid hydrolysis. Cellulose nanocrystals were oxidized by sodium periodate $\left(\mathrm{NaIO}_{4}\right)$ for functionalization. The prepared cellulose nanocrystals were characterized by Transmission electron microscopy (TEM) and Fourier transform infrared spectroscopy (FTIR) then gentamicin conjugation studies were carried out. Gentamicin conjugated cellulose nanoparticles were examined for antimicrobial activity against Escherichia coli (E. coli), Staphylococcus aureus (S. Aureus), Pseudomonas aeruginosa(aeruginosa), Klebsiella pneumoniae (K. pneumoniae) and antifungal activity against Candida albicans (C. Albicans). The results confirmed that the periodate oxidized cellulose nanocrystals are effective on bacterai and fungus.
\end{abstract}

Keywords: Waste cotton, cellulose nanocrystal, mixed acid hydrolysis method, gentamicin, antimicrobial activity.

\section{Gentamisin Konjuge Selüloz Nanokristallerinin Hazırlanması ve Farklı Mikroorganizmalar Üzerindeki Etkinliğinin Değerlendirilmesi}

$\ddot{O} \mathbf{z}$

Tekstil üretiminde ortaya çıkan büyük miktarlardaki atık pamuk malzemesi, çevre sorunlarına ve kaynakların tükenmesine neden olmaktadır. Atık pamuğun geri dönüştürülmesinin en etkili yollarından biri nanokristalin selüloz üretimidir. Selüloz nanokristaller, çeşitli özelliklerinden dolayı biyomedikal uygulamalarda büyük ilgi görmektedir. Bu çalışmada atık pamuktan asit hidrolizi ile selüloz nanokristaller tek aşamada üretilmiştir. Selüloz ekstraksiyonu, atık pamuktan alkali muamelesi ile gerçekleştirildikten sonra selüloz nanokristaller, nitrik asit $(\% 68 \mathrm{w} / \mathrm{w})$ ve hidroklorür asit $(\% 37 \mathrm{w} / \mathrm{w})$ karışımı asit hidroliz metodu ile izole edilmiştir. Selüloz nanokristaller, sodyum periyodat $\left(\mathrm{NaIO}_{4}\right)$ ile oksitlenerek modifiye edilmiştir. Hazırlanan selüloz nanokristaller, Transmisyon elektron mikroskobu (TEM) ve Fourier dönüşümlü kızı̈ötesi spektroskopisi (FTIR) ile karakterize edildikten sonra gentamisin konjugasyon çalışmaları yapılmıştır. Gentamisin konjuge selüloz nanopartiküllerin, Escherichia coli (E. coli), Staphylococcus aureus (S. aureus), Pseudomonas aeruginosa (P. aeruginosa), Klebsiella pneumoniae (K. pneumoniae)'ye karşı antimikrobiyal aktiviteleri ve Candida Albicans'a (C. albicans) karşı antifungal etkisi araştırılmıştır. Sonuçlar, periyodat oksitlenmiş selüloz nanokristallerinin bakteri ve mantar üzerinde etkili olduğunu doğrulamıştır.

Anahtar Kelimeler: Atık pamuk, selüloz nanokristal, karışık asit hidroliz metodu, gentamisin, antimikrobiyal aktivite

${ }^{*}$ Corresponding Author: gaydan@mu.edu.tr 


\section{Introduction}

Large quantities of cotton products are produced and used around the world, causing major environmental problems as well as a great waste of natural resources. There is a great concern that if the waste cotton is not disposed of properly, it will create many problems such as environmental pollution and waste of resources. Environmental and waste management of cotton could be improved by the production of cellulose nanocrystals from waste cotton. The waste cotton is the potential source for production of nano crystalline cellulose Waste cotton consists mainly of cellulose (>95-99\%) (Satyamurthy et al., 2011), is one of the most important sources used for obtaining cellulose. Cellulose nanocyristalas can be prepared from many sources through acid hydrolysis (Chen et al., 2018). The sulfuric acid hydrolysis method is the most widely used method for producing cellulose nanocrystals. Apart from sulfuric acid, mineral acids such as hydrochloric, nitric acid are also used for cellulose extraction. Strong acids remove amorphous parts and yields a highly crystalline parts.

Cellulose, is a polymer of anhydro- $\beta$-D-glycopyranose units linked with via $1 \rightarrow 4$ glycoside bonds (Muñoz-Bonilla et al., 2019). Cellulose have wide application areas in various fields with their superior properties such as strong mechanical properties, low density, biodegradability and biocompatibility (Lin et al., 2014, Wei et al., 2014, İslam et al., 2018). Cellulose can be chemically modified by partial oxidation with sodium periodate for production of carbonyl groups. The oxidation of cellulose, provides more active sites on the cellulose chains. The oxidation of cellulose with sodium periodate is known to cleave the $\mathrm{C} 2-\mathrm{C} 3$ single bonds of the D-glucopyranose units yielding so called dialdehyde cellulose (Dacrory et al., 2019). In this way, cellulose can be used in different applications such as drug carrier, separation of protein and adsorption of heavy metal.

Many infectious diseases are occurring and new effective drug systems and alternative materials with antimicrobial and antifungal bioactive properties should be investigated for their treatment (Balasubramaniam et al., 2021). The rapid emergence of resistant bacteria threatens the effectiveness of antibiotics that save millions of lives. Along with this Candida spp. is one of the most common cause of invasive fungal infections and is resistant to antifungal agents therefore new antifungal approaches should be investigated in order to eliminate the phenomenon of resistance in Candida spp. Moreover, antibiotics require frequent administration (several times a day) due to their rapid metabolism. Antibiotics generally have low bioavailability due to their limited retention time in the blood. To overcome this obstacles, scientists are researching for novel and more efficient way to deliver antibiotics. Recently various drugs are incorporated along with nanoparticles to enhance its antimicrobial nature. Gentamicin is the class of drug known as an aminoglycoside antibiotic, widely used in clinical applications due to its broad antibacterial spectrum, good curative effect and other advantages. In recent years, research has been carried out to find new antimicrobial activities of gentamicin, such as antifungal effects. Gentamicin has clinical applications in the treatment of various infections (Batul et al., 2020). It works by inhibition of bacterial protein synthesis (Beganovic et al., 2018). Its mechanism of action against bacteria involves by binding to the 30 s ribosomal subunit by irreversible, inhibit the initiation of transcription of mRNA and causing the formation of interrupted or denature proteins. The mechanism of action of gentamicin against fungi is to inhibit the growth of fungi by interfering with their plasma membrane functions (Chang et al., 2014).

Drug carrier systems are the method for delivery of therapeutic agents which can provide improved pharmacokinetic. For the treatment of various infectious disease, nanocarrier drug delivery systems are gaining increasing importance. Conjugation of antibacterial antifungal drugs with nanocarriers is effective in increasing the bioavailability of these drugs.

Natural polymers are known as having a great potential in biomedical applications in recent years due to enermous features such as biocompatibility with no immunological reaction and biodegredability (Coli'c 2020 et al., Tomi'c et al., 2018). Recently biopolymeric nanoparticles have attracted much attention due to their effectiveness in stabilizing and protecting the bioactive molecules from various environmental hazards degradation. Such drug transporter systems are stable for long circulation time in blood stream.

The aim of this study was to evaluate the antimicrobial activity of gentamicin conjugated cellulose nanocrystals. Cellulose was extracted from waste cotton with pretreatment procedures and cellulose crystals were obtained through acid hydrolysis using nitric and hydrochloric mixture acids. Prepared nanocrystals were oxidized by sodium periodate to yield carbonyl $(\mathrm{C}=\mathrm{O})$ groups. Cellulose nanoparticles having carbonyl functionality was treated with gentamicin and conjugated by this way. Gentamicin conjugated cellulose nanocrtystals' antimicrobial effect were evaluated against Escherichia coli, Staphylococcus aureus, Pseudomonas aeruginosa, Klebsiella pneumoniae and antifungal activity against Candida albicans.

\section{Material and Method}

\subsection{Material}

Waste Cotton was supplied from Ege University textile engineering department, Sodium Hydroxide ( $\mathrm{NaOH})$ (Merck), Sodium Hypochlorite $(\mathrm{NaClO})$ (Merck), Nitric acid $\left(\mathrm{HNO}_{3}\right)$ (Merck), Hydrochloric Acid ( $\mathrm{HCl})$ (Merck), Sodium periodate $\left(\mathrm{NaIO}_{4}\right)$ (Merck), Acetic Acid $\left(\mathrm{CH}_{3} \mathrm{COOH}\right)$ (Merck), Sodium Acetate $\left(\mathrm{C}_{2} \mathrm{H}_{3} \mathrm{NaO}_{2}\right)$ (Merck), Sodium Phosphate Dibasic ( $\left.\mathrm{Na}_{2} \mathrm{HPO} 4\right)$ (Merck), Sodium Phosphate Monobasic $\left(\mathrm{NaH}_{2} \mathrm{PO} 4\right)$ (Merck), Gentamicin (Sigma), Nutrient Broth Medium (Merck), Antimicrobial Susceptibility Discs (Thermo Fisher Scientific), Mueller-Hinton Broth (Merck), Microorganisms (Escherichia coli, Staphylococcus aureus, Pseudomonas aeruginosa, Klebsiella pneumoniae and Candida albicans) supplied from Muğla Sitkı Koçman University Vocational School of Health Services. All solutions were prepared with distilled water.

\subsection{Method}

\subsubsection{Preparation of cellulose nanocrystals}

Cellulose nanocrystals were prepared from waste cotton. Pretreatment process was realized initially. Then mixed acid method was evaluated to hydrolysis cellulose (Xiong et al., 2012). Cellulose nanocrystals were obtained in a single step. Briefly $1 \mathrm{~g}$ of waste cotton was cut into small pieces and treated with $100 \mathrm{~mL}$ of $3 \% \mathrm{NaOH}$ and boiled while magnetical stirring for $6 \mathrm{~h}$, to clean and remove other organic impurities. The resultant mass was coolled, and washed with distilled water until pH 7 was achieved. For the decolorazition the residue was boiled and treated with 100 $\mathrm{mL}$ of $0.6 \% \mathrm{NaClO}$ for $30 \mathrm{~min}$, then filtered and washed with distilled water until to neutral $\mathrm{pH}$. The cleaned and decolorized 
sample was subjected to acid hydrolysis. The mixed solution of nitric acid $(68 \% \mathrm{w} / \mathrm{w})$, hydrochloric acid $(37 \% \mathrm{w} / \mathrm{w}))$ and distilled water $(1: 2: 2)(\mathrm{v} / \mathrm{v})$ was prepared and $100 \mathrm{~mL}$ of this solution was added to the sample at $60{ }^{\circ} \mathrm{C}$ and stirred for 1 hour. After completed hydrolysis, the sample was filtered and washed with distilled water until the neutralization. The sample was dried at room temperature.

\subsubsection{Morphological investigation and FTIR analysis}

The size and shape of the cellulose particles were examined by TEM (FEI, model Tecnai $\mathbf{G}^{\mathbf{2}}$ Spirit BioTwin) Nanocrystal solution was diluted with distilled water and sonicated. A drop of sample was mounted onto a carbon grid and air dried. The sample was then examined by TEM.

FTIR analysis were performed to confirm the presence of carbonyl group. Samples were ground with dried KBr to prepare tablets. FTIR spectra of samples were realized using Nicolet IS10 spectrophotometer (Thermo Scientific) at room temperature from 3750 to $600 \mathrm{~cm}^{-1}$ with 32 scans at a resolution of $16 \mathrm{~cm}^{-1}$.

\subsubsection{Sodium Periodate $\left(\mathrm{NaIO}_{4}\right)$ oxidation}

$12 \mathrm{mg}$ cellulose nanocrystals were dispersed in $1 \mathrm{ml}$ of distilled water and sonicated for 20 minutes and $250 \mu \mathrm{L}$ of dispersed cellulose nanoparticles was taken and completed to 5 $\mathrm{ml}$ with $0.1 \mathrm{M} \mathrm{pH}$ : 4.5 acetic acid-sodium acetate buffer. Five different $\mathrm{NaIO}_{4}$ concentration was prepared for oxidation procedure to determine optimum $\mathrm{NaIO}_{4}$ concentration. $0.1-0.5 \mathrm{~g}$ $\mathrm{NaIO}_{4}$ was added into the each vessel to obtain $2-10 \%(\mathrm{w} / \mathrm{v})$ $\mathrm{NaIO}_{4}$ concentration. The reaction vessels were kept in the dark for 2 hours. After the mixtures were centrifuged at 4,000 rpm for 15 minutes, $500 \mu \mathrm{L} \mathrm{pH}$ : 7.4 phosphate buffer was added to the precipitated parts and sonicated for half an hour.

\subsubsection{Preparation of gentamicin conjugated cellulose nanocrystals}

Drug conjugation studies were evaluated by incubation method. Briefly $200 \mu \mathrm{l}$ of periodate-oxidized cellulose nanocrystals $(3 \mathrm{mg} / \mathrm{mL})$ were dissolved in phosphate buffer mixed with $400 \mu \mathrm{L}$ gentamicin $(40 \mathrm{mg} / \mathrm{mL})$. After the samples were mixed in the dark for 3 hours on the magnetic stirrer, the samples were centrifuged at $4000 \mathrm{rpm}$ for 15 minutes. Pellet was dissolved again by adding $500 \mu \mathrm{l}$ pH:7.4 phosphate buffer on the precipitated parts. This process was repeated 3 times. Conjugated drug amount to the cellulose nanocrystals were calculated by using the indirect method. Unbound gentamicin was calculated by the difference between the initial drug amount and the free amount of drug in the supernatant.

\subsubsection{Antibacterial activity and Antifungal activity}

The antimicrobial activity test of the samples was performed using the disk diffusion (DD) method (Bauer, 1966). Microorganisms were cultivated in tubes containing Nutrient Broth. 4 bacteria (E. coli, $S$. aureus, $P$. aeruginosa, $K$. pneumoniae) were incubated at $37^{\circ} \mathrm{C}$ and $C$. albicans was incubated at $25^{\circ} \mathrm{C}$ for 24 hours, so microorganisms were activated. At the end of the incubation, the microorganism was inoculated with $10^{6-1} 10^{7} \mathrm{CFU} / \mathrm{ml}$ by spreading method on MuellerHinton Agar medium and waited for 30 minutes for the microorganisms to be absorbed. After the microorganisms were ready, antibiogram discs were placed in petri dishes with a distance of $2 \mathrm{~cm}$ between them. $40 \mu \mathrm{L}$ of gentamicin conjugated cellulose nanoparticles were added to the antibiogram discs. Cellulose nanocrystals without gentamicin conjugation were used for control. Petri dishes were incubated at $37^{\circ}$ for 48 hours and antimicrobial effects of samples on the microorganism were examined. The inhibition diameter zones were measured $(\mathrm{mm})$ and photographed.

\section{Results and Discussion}

\subsection{Cellulose nanocrystal preparation}

In this study cellulose was obtained from waste cotton by applying alkaline bleaching treatments which is called pretreatment. Pretreatments are generally used for the produce pure cellulose from different cellulose sources (El Achaby et al., 2018a). The non cellulosic compounds such as hemicellulose, lignin and others are removed by this process. Waste cotton is treated with alkali to dissolve hemicellulose, followed by bleaching to remove lignin (Trachea et al., 2014). Cellulose fibers than subjected to acid hydolysis. Cellulose nanocyristals are primarily obtain from waste cotton by mineral acid hydrolysis (hydrochloric, sulfuric acid, nitric acid etc.) The mechanism of hydrolysis is that the acid hydrogen ions can easily attack the amorphous regions of the cellulose to break the $1 \rightarrow 4$ glycoside bonds so that the amorphous regions are removed (Tan et al., 2015). The most commonly used hydrolysis method for producing cellulose nanocrystals is sulfuric acid hydrolysis method (Huang et al.,2020). However, sulfuric acid has many drawbacks. Sulfuric acid is a strong acid, hydolysis reaction result in lower yields due to the excess degradation. Therefore, recently, increased efforts have been made to use other mineral acids alternative to sulfuric acid (Liu et al., 2014). $\mathrm{HNO}_{3}$ (nitric acid) is as an alternative to the strong acids in the cellulose isolation. Because it is miscible in water and has less corrosive character. $\mathrm{HNO}_{3}$ was used to remove amorphous region of cellulose that contribute increasing the cellulosic yield. $\mathrm{HCl}$ (Hydrochloric acid) is also commonly used for the isolation of cellulose nanocrystals. Hydrolysis with $\mathrm{HCl}$ ensures that the superficial hydroxyl groups remain unmodified (Kassab et al., 2019a). Therefore, mixture of $\mathrm{HNO}_{3}$ and $\mathrm{HCl}$ were used for more efficient isolation of cellulose nanocrystals. As a result, by using $\mathrm{HNO}_{3}$ and $\mathrm{HCl}$, the properties of cellulose crystals were improved in terms of yield, purity and crystallinity (Hanani et al.,2017, Chauhan et al.,2010).

\subsection{Cellulose modification and Gentamicin conjugation}

The oxidation of cellulose is a very important reaction in cellulose chemistry. This reaction produces new group and reactive sites, such as carbonyl groups. The oxidation method with sodium periodate is one of the most used methods for the functionalization of cellulose. Sodium periodate oxidized cellulose is biodegradable and biocompatible (Maia et al., 2017). Each glucose unit in the cellulose molecule contains three hydroxyl groups, at the C6 position (primary alcohol) and two at the $\mathrm{C} 2$ and $\mathrm{C} 3$ positions (secondary alcohols), which are primarily responsible for the functionalization of cellulose. In this study after cellulose nanocrystal preperation steps, C2-C3 carbons in the glucose ring are selectively broken as a result of sodium periodate oxidation, revealing dialdehyde groups, yielding 2,3dialdehyde cellulose (Errokh et al.,2018). 


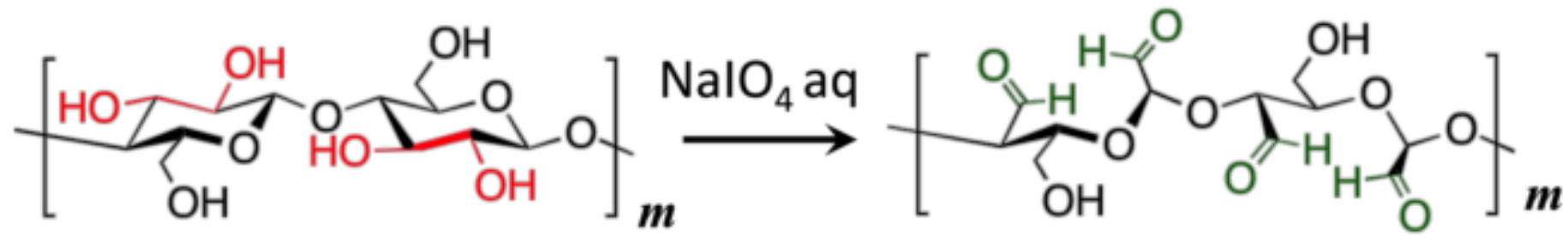

Figure 1. The principle of periodate oxidation of cellulose (Hell et al., 2020).

To obtain the effective oxidation efficiency, oxidation reaction of cellulose nanoparticles was performed at $2-10 \%$ periodate concentrations. Synthetically oxidized cellulose is capable of binding of a large amount of gentamicin due to a high density of ligating groups. The most suitable periodate oxidation contentration was found as $4 \%$ periodate concentration with 30 min reaction time to prepare gentamicin conjugated cellulose nanocrystals. Gentamicin was attached via imine bonds. Imine bonds are formed through conjugation of the $\mathrm{NH}_{2}$ groups of gentamicin and the carbonyl groups of the functionalized celulose nanocrystals. The formation of carbonyl groups through oxidation, functionalizes cellulose. This provides the possible interaction of amine compounds and cellulose and the formation of a Schiff base (Kim et al., 2000). Many biomedical applications were performed with periodate oxidized cellulose. In a study theophylline was loaded into the functionalized cellulose-chitosan hydrogels (Xu et al., 2019). In another study periodate-oxidized cellulose was modified with polyethyleneimine to prepare cellulose membranes with antibacterial activity (Zhang et al., 2019).

\subsection{TEM and FTIR analysis}

TEM image of cellulose nanocrystals produced from mixed acid hydrolysis process is presented in Fig 2 .

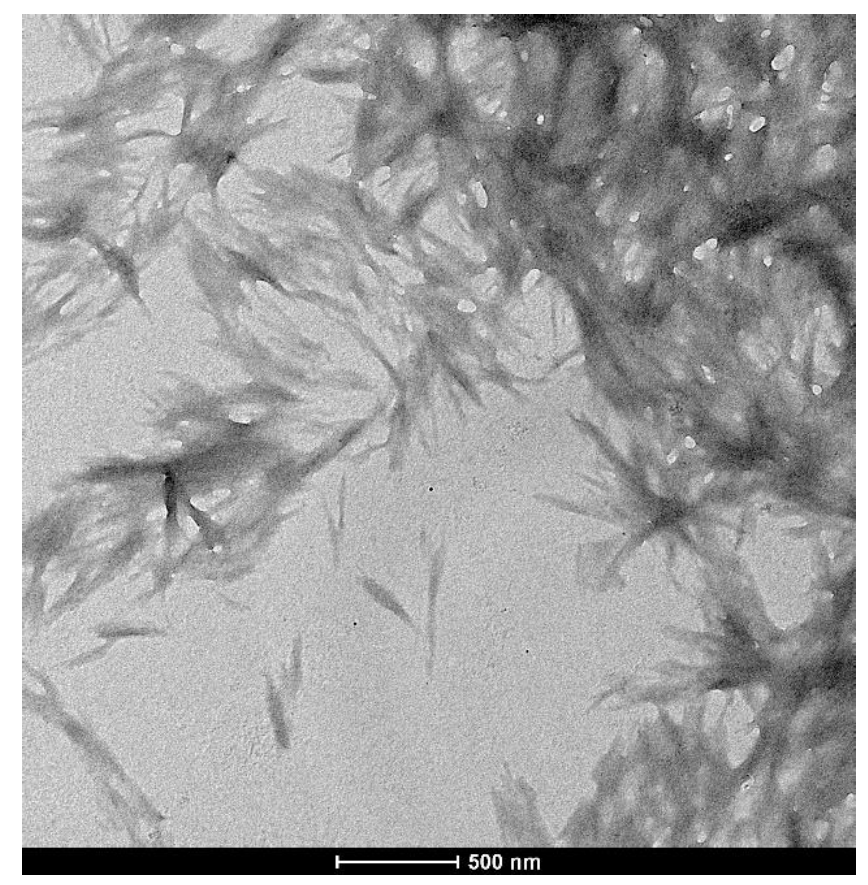

Figure 2. TEM image of cellulose nanocrystals

The TEM image shows that cellulose nanocrystals exhibited a crystalin structure below $500 \mathrm{~nm}$ in size. Nano size makes celulolose to possess high surface area. Acid hydrolysis was provided to the isolation of small cellulose nanocrystals in terms of diameter and length. The TEM image confirmed the removal of the amorphous domains (El Achaby et al. 2018b).
FTIR spectra of waste cotton, cellulose nanocrystal and periodate oxidized cellulose nanocrystal samples are shown in Figure 3. FTIR spectroscopy was used to identify the structure of the samples. Figure 3 shows the FTIR spectra of waste cotton, nanocellulose, modified cellulose. 


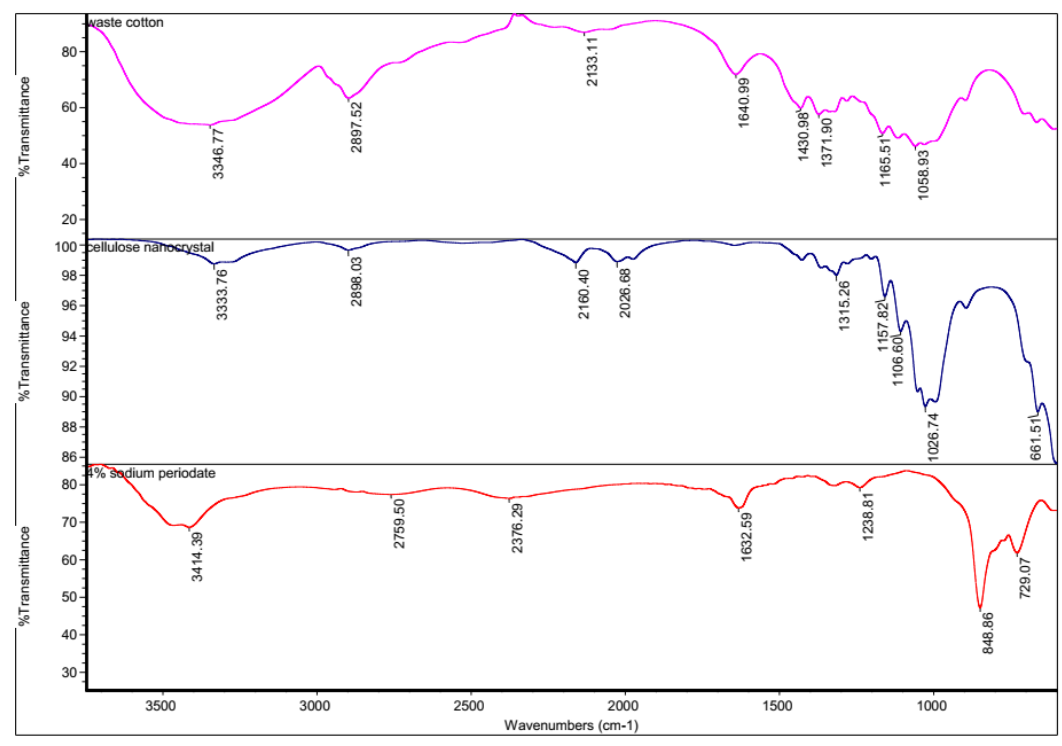

Figure 3. FTIR spectra of waste cotton, cellulose nanocrystal and peridate oxidized cellulose nanocrystal

The FTIR analysis result revealed that the presence of carbonyl group, which is formed by periodate oxidation of two secondary hydroxyl groups in the glucose molecule. When the figure is examined the broad absorption band at $3414 \mathrm{~cm}^{-1}$ is a cellulose absorption peak, because of the $\mathrm{O}-\mathrm{H}$ stretching (Yu et al., 2013). The absorption peak at $848 \mathrm{~cm}-1$ at oxidized sample is ascribed to the stretching vibrations of the glycosidic $\mathrm{C} 1-\mathrm{H}$ deformation with ring vibration contribution and $\mathrm{OH}$ bending, which is characteristic for $\beta$-glycosidic bonds (Pietrucha et al., 2015). It was observed that the absorption band at $1026 \mathrm{~cm}^{-1}$ seen in the unoxidized sample completely disappeared in the oxidized sample. This peak is known to because of $\mathrm{C}-\mathrm{O}$ from $\mathrm{C}-\mathrm{OH}$, mainly from carbon three in the anhydroglucose unit (Schwanninger et al. 2004). The newly appeared carbonyl peak at $1632 \mathrm{~cm}^{-1}$ meaning that functionalization of cellulose with sodium periodate oxidation (Nawaz et al., 2020, Coseri et al., 2015, Ahmed et al., 2005).

\subsection{Gentamicin conjugation to the cellulose nanocrystals}

Oxidized cellulose has a very good binding ability to drug molecules containing amine groups due to its carbonyl groups. In literature there are some reports about using oxidized cellulose as potential drug delivery devices. In literature there are some studies on using oxidixed celluose for delivery of different kind of drugs. Akhlaghi et al. prepared chitosan chains grafted cellulose nanoparticles as a procaine hydrochloride and imipramine hydrochloride carrier (Akhlaghi et al., 2014). Volkert et al. reported oxidized cellulose drug carrier for benzocaine and prazosin (Volkert et al., 2009). In a study Dox was loaded onto periodate oxidized cellulose nanocrystal via functional groups of Dox which contains $-\mathrm{NH}_{2}$ goups and oxidized particles (Kumari et al., 2018).
In this study, gentamicin molecule, which is known to have $\mathrm{NH}_{2}$ groups, was highly efficiently conjugated to cellulose nanoparticles due to the carbonyl groups of oxidized cellulose. Conjugated amount of drug was calculated by the difference between the initial drug amount and the free amount of drug in the supernatant. The result was very satisfactory and showed $98,12 \%$ gentamicin was conjugated to the cellulose nanocrystals. Taheri et al prepared Hydroquinone bounded cellulose nanocrystals and they reported as Hydroquinone was bound to the cellulose nanocrystals with $79.3 \%$ binding efficiency (Taheri et al., 2015).

\subsection{Antimicrobial activity effect of gentamicin conjugated cellulose nanocrystal}

The antimicrobial activity test was performed on MuellerHinton agar using the disk diffusion (DD) method. The bactericidal property of the prepared gentamicin conjugated celulose nanocrystals were evaluated against gram-negative airway pathogens $P$. aeruginosa, K. pneumoniae, $S$. aureus and $E$. coli. Antifungal activity effect of gentamicin conjugated celulose nanocrystals were also invastigated against pathogen fungi $C$. albicans. To determine antibacterial activity, the inhibition zones were measured for all samples. Gentamicin as a positive control was added for comparison. Cellulose nanocrystals without gentamicin conjugation were also evaluated as a control experiment. The photographs of agar plates showing the inhibition zones, were presented in Figure 4. 
$\mathrm{a}$

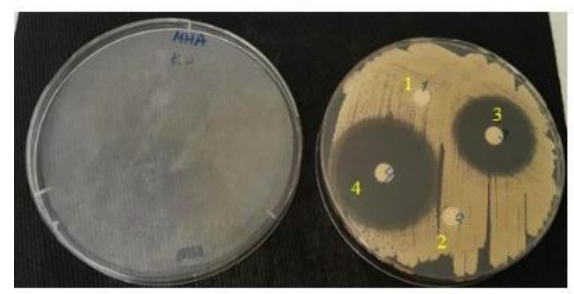

C

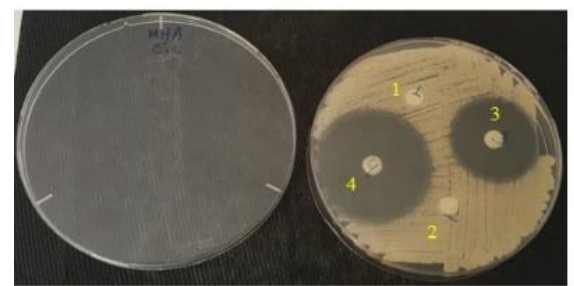

b

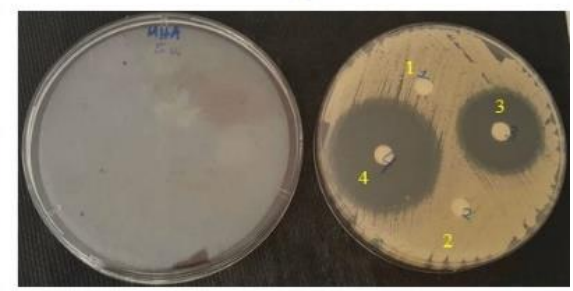

d

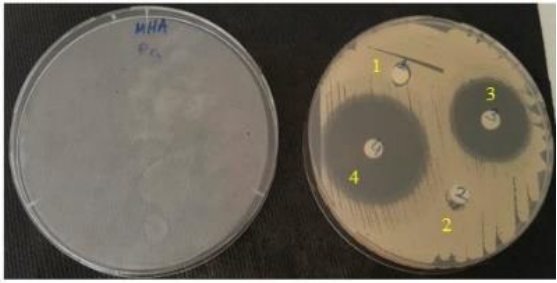

e

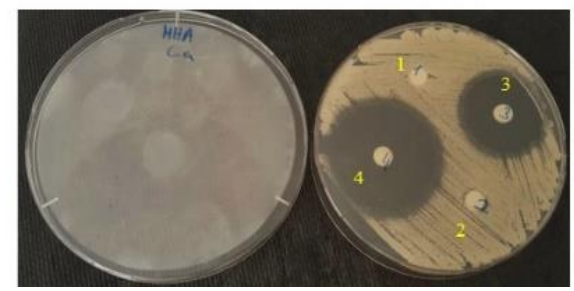

Figure 4. Antimicrobial effect image photographs of different micoorganisms

Bacteria and fungus; a) K. pneumoniae b) S. aureus c) E. coli d) P. Aeruginosa e) C. Albicans

Samples; 1:cellulose nanocrystal, 2:oxidized cellulose (4\%), 3:gentamicin conjugated cellulose nanocrystal, 4:gentamicin

The results of the zone diameters $(\mathrm{mm})$ are gathered in Table1. The modification with different periodate concentration was numbered from 1-5.

Table 1. Inhibition zone diameters of microorganisms at different $\mathrm{NaIO}_{4}$ concentrations

\begin{tabular}{|c|c|c|c|c|c|c|}
\hline No & $\begin{array}{c}\mathrm{NaIO}_{4} \% \\
\text { Concentration }\end{array}$ & \multicolumn{3}{|c|}{$\mathrm{NaIO}_{4} \%$} & eum & Ibicans \\
\hline 1 & 2 & 20 & 20 & 21 & 21 & 20 \\
\hline 2 & 4 & 33 & 33 & 34 & 32 & 32 \\
\hline 3 & 6 & 28 & 27 & 28 & 27 & 26 \\
\hline 4 & 8 & 29 & 29 & 29 & 29 & 29 \\
\hline 5 & 10 & 26 & 25 & 26 & 27 & 26 \\
\hline
\end{tabular}

The result showed that cellulose nanocrystals without gentamicin conjugation and oxidized cellulose nanocrystals exhibited no antimicrobial effect (Figure 4). The results indicated that gentamicin conjugated cellulose nanocrystals was effective against E. coli, S. aureus, $P$. aeruginosa, $K$. pneumoniae and $C$. albicans. As it seen from the Table 1 gentamicin conjugated oxidized cellulose crystals exhibited small changes in antimicrobial activity on different microorganisms. Formulation 2(\#2) $4 \%$ periodate oxidation was found to be most effective in applications. Above this periodate concentrations were not as effective as this concentration. This indicates that cellulose has an oxidation limit. The reason for that may be explained as protection of neighbouring residues by the formation of internal hemiacetals, as observed with the other polysaccharide (Vold, 2004).

It can be concluded that oxidized cellulose has ability to bind large amount of gentamicin due to carbonyl groups and effective on different kind of microrganisms. In literature there are many reports about using oxidized cellulose as potential drug delivery devices for antimicrobial drugs against Staphylococcus aureus, Methicillin-resistant Staphylococcus aureus, Bacillus subtilis, Escherichia coli, and Salmonella typhimurium (Ge, et al.2016; Mou et al.,2017; Zhang et al., 2017). 


\section{Conclusions and Recommendations}

In recent years, biomaterials obtained from natural materials have found many application areas. In this study, the concept of using mixed acid hydrolysis process $\left(\mathrm{HNO}_{3} / \mathrm{HCl}\right)$ to produce cellulose nanocrystals from low cost waste cotton material is presented. In the study, cellulose crystals of desired purity and crystallinity were obtained by using a mixture of nitric acid and hydrochloric acid, which is less corrosive, instead of sulfuric acid. The periodate concentration at which cellulose has a certain oxidation limit was determined, and drug binding studies were continued with this concentration. The carboxyl groups formed as a result of oxidation allowed more gentamicin binding. It is predicted that the preparation of the gentamicin bound cellulose nanocrystals will make a significant contribution to extending the half-life and increasing bioavailability of gentamicin.

The results showed that cellulose nanocrystals were successfully obtained from waste cotton via mixed acid hydrolysis method. The approximate ranges of length and diameter of cellulose nanocrystals extracted from cotton was below $500 \mathrm{~nm}$ in size. Gentamicin as a antimicrobial drug was succesfully conjugated to the oxidized cellulose nanocrystals $(98,12 \%)$. The result confirmed that the prepared nanocrystals were effective on all microorganisms. Gentamicin bound cellulose nanocrystals have been observed to be effective against both bacterial and fungal microorganisms.. The prepared natural nanocellulose crystals can be used as a safe and promising drug carrier for many drug applications.

\section{Acknowledge}

The authors would like to thank to Dr. Fikret Keven Karademir for microbiology labrotary facilities.

\section{References}

Ahmed, M. K. K., Rana, A. C., Dixit V.K. (2005) Calotropis species (Asclepediaceae).

A comprehensive review, Pharmacognosy Magazine, 1(2), 48-52.

Akhlaghi, S. P., Tiong, D., Berry, R. M., \& Tam, K. C. (2014). Comparative release studies of two cationic model drugs from different cellulose nanocrystal derivatives. European Journal of Pharmaceutics and Biopharmaceutics, 88(1), 207215.

Balasubramaniam, B., Prateek, Ranjan, S., Saraf, M., Kar, P., Singh, S. P., ... \& Gupta, R. K. (2020). Antibacterial and Antiviral Functional Materials: Chemistry and Biological Activity toward Tackling COVID-19-like Pandemics. ACS Pharmacology \& Translational Science.

Batul, R., Bhave, M., J Mahon, P., \& Yu, A. (2020). Polydopamine Nanosphere with In-Situ Loaded Gentamicin and Its Antimicrobial Activity. Molecules, 25(9), 2090.

Bauer, A. T. (1966). Antibiotic susceptibility testing by a standardized single disc method. Am J clin pathol, 45, 149158.

Beganovic, M., Luther, M. K., Rice, L. B., Arias, C. A., Rybak, M. J., \& LaPlante, K. L. (2018). A review of combination antimicrobial therapy for Enterococcus faecalis bloodstream infections and infective endocarditis. Clinical Infectious Diseases, 67(2), 303-309.
Chang, C. W., \& Takemoto, J. Y. (2014). Antifungal amphiphilic aminoglycosides. MedChemComm, 5(8), 1048-1057.

Chauhan Y. P., Khedkar S. V., Bhagat S. L. \& Pardey A. P. (2010). A comparative study of acid hydrolysis of cellulosic waste (Waste of Hosiery Industry) for manufacturing microcrystalline cellulose. Int. J. Chem. Sci., 8(4), 2227-2235.

Chen, X. Q., Deng, X. Y., Shen, W. H., \& Jia, M. Y. (2018). Preparation and characterization of the spherical nanosized cellulose by the enzymatic hydrolysis of pulp fibers. Carbohydrate polymers, 181, 879-884.

Čolić, M., Tomić, S., \& Bekić, M. (2020). Immunological aspects of nanocellulose. Immunology letters.

Coseri, S., Biliuta, G., Zemljič, L. F., Srndovic, J. S., Larsson, P. T., Strnad, S., ... \& Lindström, T. (2015). One-shot carboxylation of microcrystalline cellulose in the presence of nitroxyl radicals and sodium periodate. $R S C$ advances, 5(104), 85889-85897.

Dacrory, S., Abou-Yousef, H., Kamel, S., Abou-Zeid, R. E., Abdel-Aziz, M. S., \& Elbadry, M. (2019). Functionalization and cross-linking of carboxymethyl cellulose in aqueous media. Cell Chem Technol, 53(1-2), 11.

El Achaby, M., El Miri, N., Hannache, H., Gmouh, S., Trabadelo, V., Aboulkas, A., \& Youcef, H. B. (2018 a). Cellulose nanocrystals from Miscanthus fibers: insights into rheological, physico-chemical properties and polymer reinforcing ability. Cellulose, 25(11), 6603-6619.

El Achaby, M., Kassab, Z., Aboulkas, A., Gaillard, C., \& Barakat, A. $(2018 \mathrm{~b})$. Reuse of red algae waste for the production of cellulose nanocrystals and its application in polymer nanocomposites. International journal of biological macromolecules, 106, 681-691.

Errokh, A., Magnin, A., Putaux, J. L., \& Boufi, S. (2018). Morphology of the nanocellulose produced by periodate oxidation and reductive treatment of cellulose fibers. Cellulose, 25(7), 3899-3911.

Ge, H., Zhang, L., Xu, M., Cao, J., \& Kang, C. (2016, November). Preparation of dialdehyde cellulose and its antibacterial activity. In International Conference on Applied Biotechnology (pp. 545-553). Springer, Singapore.

Hanani, A. N., Zuliahani, A., Nawawi, W. I., Razif, N., \& Rozyanty, A. R. (2017, May). The effect of various acids on properties of microcrystalline cellulose (MCC) extracted from rice husk (RH). In IOP Conference Series: Materials Science and Engineering (Vol. 204, No. 1, p. 012025). IOP Publishing.

Hell, S., Ohkawa, K., Amer, H., Potthast, A., \& Rosenau, T. (2020). A General Protocol for Electrospun Non-Woven Fabrics of Dialdehyde Cellulose and Poly (Vinyl Alcohol). Nanomaterials, 10(4), 671.

Huang, S., Liu, X., Chang, C., \& Wang, Y. (2020). Recent developments and prospective food-related applications of cellulose nanocrystals: A review. Cellulose, 27(6), 29913011.

Islam, M. S., Chen, L., Sisler, J., \& Tam, K. C. (2018). Cellulose nanocrystal (CNC)-inorganic hybrid systems: synthesis, properties and applications. Journal of Materials Chemistry $B, 6(6), 864-883$.

Kassab, Z., Hannache, H., \& El Achaby, M. (2019). Isolation of cellulose nanocrystals from various lignocellulosic materials: physico-chemical characterization and application in polymer composites development. Materials Today: Proceedings, 13, 964-973. 
Kim, U. J., \& Kuga, S. (2000). Reactive interaction of aromatic amines with dialdehyde cellulose gel. Cellulose, 7(3), 287297.

Kumari, S., Ram, B., Kumar, D., Ranote, S., \& Chauhan, G. S. (2018). Nanoparticles of oxidized-cellulose synthesized by green method. Materials Science for Energy Technologies, 1(1), 22-28.

Lin, N., \& Dufresne, A. (2014). Nanocellulose in biomedicine: Current status and future prospect. European Polymer Journal, 59, 302-325.

Liu, Y., Wang, H., Yu, G., Yu, Q., Li, B., \& Mu, X. (2014). A novel approach for the preparation of nanocrystalline cellulose by using phosphotungstic acid. Carbohydrate polymers, 110, 415-422.

Maia, T. H. S., Larocca, N. M., Beatrice, C. A. G., de Menezes, A. J., de Freitas Siqueira, G., Pessan, L. A., ... \& de Almeida Lucas, A. (2017). Polyethylene cellulose nanofibrils nanocomposites. Carbohydrate polymers, 173, 50-56.

Mou, K., Li, J., Wang, Y., Cha, R., \& Jiang, X. (2017). 2, 3Dialdehyde nanofibrillated cellulose as a potential material for the treatment of MRSA infection. Journal of Materials Chemistry B, 5(38), 7876-7884.

Muñoz-Bonilla, A., Echeverria, C., Sonseca, Á., Arrieta, M. P., \& Fernández-García, M. (2019). Bio-based polymers with antimicrobial properties towards sustainable development. Materials, 12(4), 641.

Nawaz, A. (2020). Composite of natural bamboo (Dendrocalamus strictus) and $\mathrm{TiO} 2$ : Its photocatalytic potential in the degradation of methylene blue under the direct irradiation of solar light. Research on Chemical Intermediates, 1-17.

Pietrucha, K., \& Safandowska, M. (2015). Dialdehyde cellulosecrosslinked collagen and its physicochemical properties. Process Biochemistry, 50(12), 2105-2111.

Satyamurthy, P., Jain, P., Balasubramanya, R. H., \& Vigneshwaran, N. (2011). Preparation and characterization of cellulose nanowhiskers from cotton fibres by controlled microbial hydrolysis. Carbohydrate Polymers, 83(1), 122129.

Schwanninger, M., Rodrigues, J. C., Pereira, H., \& Hinterstoisser, B. (2004). Effects of short-time vibratory ball milling on the shape of FT-IR spectra of wood and cellulose. Vibrational Spectroscopy, 36(1), 23-40.

Taheri, A., \& Mohammadi, M. (2015). The use of cellulose nanocrystals for potential application in topical delivery of hydroquinone. Chemical biology \& drug design, 86(1), 102106.

Tan, X. Y., Abd Hamid, S. B., \& Lai, C. W. (2015). Preparation of high crystallinity cellulose nanocrystals (CNCs) by ionic liquid solvolysis. Biomass and Bioenergy, 81, 584-591.

Tomić, S., Ilić, N., Kokol, V., Gruden-Movsesijan, A., Mihajlović, D., Bekić, M., ... \& Vučević, D. (2018). Functionalization-dependent effects of cellulose nanofibrils on tolerogenic mechanisms of human dendritic cells. International journal of nanomedicine, 13, 6941.

Trache, D., Donnot, A., Khimeche, K., Benelmir, R., \& Brosse, N. (2014). Physico-chemical properties and thermal stability of microcrystalline cellulose isolated from Alfa fibres. Carbohydrate polymers, 104, 223-230.

Vold, I. M. N. (2004). Periodate oxidised chitosans: structure and solution properties.

Volkert, B., Wolf, B., Fischer, S., Li, N., \& Lou, C. (2009, June). Application of modified bead cellulose as a carrier of active ingredients. In Macromolecular symposia (Vol. 280, No. 1, pp. 130-135). Weinheim: WILEY-VCH Verlag.

Wei, H., Rodriguez, K., Renneckar, S., \& Vikesland, P. J. (2014). Environmental science and engineering applications of nanocellulose-based nanocomposites. Environmental Science: Nano, 1(4), 302-316.

Xiong, R., Zhang, X., Tian, D., Zhou, Z., \& Lu, C. (2012). Comparing microcrystalline with spherical nanocrystalline cellulose from waste cotton fabrics. Cellulose, 19(4), 11891198.

Xu, Q., Ji, Y., Sun, Q., Fu, Y., Xu, Y., \& Jin, L. (2019). Fabrication of cellulose nanocrystal/chitosan hydrogel for controlled drug release. Nanomaterials, 9(2), 253.

Yu, H., Qin, Z., Liang, B., Liu, N., Zhou, Z., \& Chen, L. (2013). Facile extraction of thermally stable cellulose nanocrystals with a high yield of $93 \%$ through hydrochloric acid hydrolysis under hydrothermal conditions. Journal of Materials Chemistry A, 1(12), 3938-3944.

Zhang, L., Ge, H., Xu, M., Cao, J., \& Dai, Y. (2017). Physicochemical properties, antioxidant and antibacterial activities of dialdehyde microcrystalline cellulose. Cellulose, 24(5), 2287-2298.

Zhang, S., Kai, C., Liu, B., Zhang, S., Wei, W., Xu, X., \& Zhou, Z. (2019). Preparation, characterization and antibacterial properties of cellulose membrane containing $\mathrm{N}$ halamine. Cellulose, 26(9), 5621-5633. 